Flesh Wounds 
This page intentionally left blank 


\section{Flesh Wounds}

The Culture of Cosmetic Surgery

Virginia L. Blum

UNIVERSITY OF CALIFORNIA PRESS

Berkeley Los Angeles London 
University of California Press

Berkeley and Los Angeles, California

University of California Press, Ltd.

London, England

(C) 2003 by the Regents of the University of California

\section{Library of Congress Cataloging-in-Publication Data}

Blum, Virginia L., I956-.

Flesh wounds: the culture of cosmetic surgery / Virginia

L. Blum.

p. $\mathrm{cm}$.

Includes bibliographical references and index.

ISBN $0-520-2$ I $723-3$ (cloth : alk. paper)

I. Surgery, Plastic-Social aspects. 2. Surgery,

Plastic_Psychological aspects. I. Title.

RDII9.B $88 \quad 2003$

6 I $7.9^{\prime} 5-\mathrm{dc} 2 \mathrm{I}$

2002 I 54915

Manufactured in the United States of America

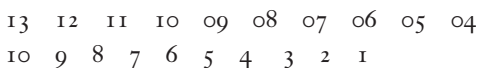

The paper used in this publication is both acid-free and totally chlorine-free (TCF). It meets the minimum requirements of ANSI/NISO Z39.48-I992 (R 1997)

(Permanence of Paper). 
To my father, David Blum and to my mother, Fern Walder 
This page intentionally left blank 